\title{
ANALISIS PEMILIHAN REGION OF INTEREST (ROI) PADA MAGNETIC RESONANCE SPECTROSCOPY (MRS)
}

\section{ANALYSIS REGION OF INTEREST (ROI) ELECTION IN MAGNETIC RESONANCE SPECTROSCOPY (MRS)}

\author{
Anita Nur Mayani ${ }^{1)}$, Gatot Murti Wibowo ${ }^{2)}$ Darmini $^{3)}$ \\ ${ }^{1,2,3)}$ Health Polytechnics of Semarang-Indonesia \\ e-mail: anitanurmayani@gmail.com
}

\begin{abstract}
Background: Magnetic Resonance Spectroscopy (MRS) is an advance examination of MRI which produces a spectra describes metabolic information of tissues. ROI setting was very important in producing the spectra with diagnostic value that called Full-Width at Half Maximum (FWHM). In clinical applications, Radiographers select several ROIs in obtaining FWHM values without any specific benchmark which in turn directly affects on the accuracy of staging brain tumor. This study aims to examine the FWHM profiles based on the ROI selections, and to determine the effect of selected ROIs to FWHM values.

Methods: This research was a quantitative study with an experimental approach. Data were assessed by an expert Radiographer during a period of 30 days on June 2016 in Radiology Department of Siloam Kebon Jeruk Jakarta Hospital using a specific bottle phantom MRI 2000 $\mathrm{ml}$. The phantom was scanned with 1.5 Tesla MRI scanner, wuth various selection of the ROIs sized $20 \mathrm{~mm}, 25 \mathrm{~mm}, 30 \mathrm{~mm}, 35 \mathrm{~mm}$ and 40 $\mathrm{mm}$ at the centre position, 12 o'clock position, 3 o'clock position, 6 o'clock position and 9 o'clock position. Data was analyzed using linier regression test of SPSS V.16 software. The confident interval of influence of the ROI size in producing FWHM values was $95 \%$.

Results: The results showed the optimum FWHM values, 12-20, produced from the ROI size of 20-30 mm at the centre position. Regression analysis showed significant result ( $p$-value $<0.05$ ), which was null hypothesis was rejected. It can be concluded that the ROI size setting effected on the resulted FWHM values. The smaller ROI size, FWHM value will decrease with higher homogeneity and vise versa. Conclusion: Optimum FWHM value was produced by ROI size of $20-30 \mathrm{~mm}$ at the centre position. There was influence of ROI size setting to FWHM value.
\end{abstract}

Keywords: magnetic resonance spectroscopy, region of interets, full width at half maximum

\section{PENDAHULUAN}

Penyakit kanker merupakan salah satu penyebab kematian utama di seluruh dunia. Pada tahun 2012, sekitar 8,2 juta kematian disebabkan oleh kanker. Menurut William (2007) 25\% dari seluruh pasien kanker mengalami metastasis ke otak membentuk brain tumor. Salah satu metode diagnostik yang dipilih untuk mendiagnosis brain tumor adalah Magnetic Resonance Imaging (MRI). Pemeriksaan fungsional organ menggunakan MRI scanner dengan diagnosis brain tumor akan lebih informatif apabila ditambahkan pemeriksaan MRI advance yaitu Magnetic Resonance Spectroscopy (MRS).

MRS adalah prosedur yang tersedia pada MRI scanner klinis yang dapat memberikan informasi klinis yang relevan pada jenis penyakit seperti tumor, gangguan metabolisme dan penyakit sistemik. MRS biasa digunakan untuk melihat metabolit jaringan seperti liver, prostat, breast dan paling sering digunakan pada otak. Output dari MRS adalah kumpulan dari beberapa peak yang masing-masing mewakili unsur kimia metabolit otak dari suatu area yang dipilih.Kumpulan beberapa peak tersebut membentuk spektrum yang perlu dilakukan interpretasi untuk dapat menegakkan diagnosa(Blüml, 2013).

Bila pada citra MRI menggambarkan distribusi dan interaksi air (proton ${ }^{1} \mathrm{H}$ ) pada jaringan, sebaliknya pada MRS menganalisis sinyal proton hidrogen yang terikat dengan molekul lain pada metabolit otak. Metabolit di otak yang mengandung proton yang dapat diukur dengan MRI scanner
1,5 Tesla adalah unsur kimia $N$-acetyl aspartate (NAA), $N$ acetylaspartylglutamate (NAAG), creatine atau phosphocreatine $(\mathrm{Cr})$, choline atau phosphocholine atau glycerophosphorylcholine (Cho), glutamate (Glu) dan glutamine (Gln). Pada tumor jinak terdapat peningkatan choline dan penurunan creatine dan NAA, sedangkan pada tumor ganas terdapat peningkatan yang lebih pada choline dan peningkatan lipid dan lactate (John, 2004).

Pada MRS terdapat dua teknik, yaitu teknik single voxel spectroscopy (SVS) dan teknik chemical shift imaging (CSI). SVS adalah teknik yang digunakan untuk merekam spektrum dari satu daerah otak pada satu waktu, sedangkan CSI dapat sekaligus merekam spektrum dari beberapa daerah sehingga mampu menggambarkan distribusi spasial metabolit dalam otak.Teknik SVS dipilih untuk mengevaluasi tumor otak sehingga didapatkan informasi metabolit lebih optimal (Horská 2011).

Pada MRS terdapat perbedaan dengan MRI, dibutuhkan langkah tambahan yang penting yaitu pengaturan region of interest (ROI) menggunakan citra yang telah diperoleh dari MRI rutin yang dilakukan. Karena unsur kimia yang dapat terdeteksi MRI memiliki konsentrasi yang rendah, MRS dibatasi untuk menganalisis pada ROI tertentu yang memiliki resolusi jauh lebih besar dari resolusi MRI. Tidak hanya membutuhkan operator yang dapat memutuskan lokasi yang sesuai, tetapi juga terdapat faktor lain seperti ukuran, 
averaging yang dibutuhkan untuk mendapatkan spektrum dengan kualitas optimal, meminimalkan volume parsial dengan jaringan disekitarnya, menghindari objek tulang, darah, udara dan cairan cerebrospinal.

Menurut Xu (2012), untuk mendapatkan nilai diagnostik dari MRS, terdapat faktor teknis yang perlu diperhatikan salah satunya adalah prescan adjustment shimming yang ditetapkan oleh full-width at half maximum (FWHM) dalam domain frekuensi. Prescan adjustment shimming dilakukan untuk meningkatkan homogenitas medan magnet dari ROI yang akan dinilai pada MRS. Hal ini menentukan kemampuan MRS dalam menghasilkan spektrum yang baik. Pada awal munculnya MRS, spectroscopist selalu melakukan prescan adjustment shimming. Saat ini pesawat MRI dapat secara otomatis melakukan prescan adjustment shimming, namun penggunaan prescan adjustment shimming secara manual dapat menghasilkan spektrum yang lebih optimal.Spektrum yang baik diperoleh dari ROI yang tidak terlalu kecil dan tidak terlalu besar dan tidak berada pada pada area perdarahan, kalsifikasi, tulang dan udara. Bila ukuran voxel terlalu kecil akan menghasilkan spektrum dengan signal to noise (SNR) yang rendah (Bluml, 2013).

Pada pemeriksaan MRS terdapat ketidakpastian dalam pemilihan ROI oleh radiografer. Pemilihan ukuran ROI diatur dengan ukuran 20x20x20 atau ROI sebesar ukuran tumor. Ketidakpastian dalam pemilihan ROI ini akan berpengaruh pada prosedur MRS selanjutnya, yaitu pada proses prescan adjustment shimming dalam menghasilkan nilai FWHM yang menentukan kualitas spektrum yang dihasilkan MRS.

\section{METODE}

Jenis penelitian ini adalah penelitian kuantitatif dengan pendekatan eksperimental. Pengambilan data dilakukan pada bulan Juni 2016 di Radiology Department of Siloam Hospital Kebon Jeruk. Populasi dan sampel penelitian adalah ROI pada scanning phantom MRS axial pada ukuran ROI: $20 \mathrm{~mm}, 25$ $\mathrm{mm}, 30 \mathrm{~mm}, 35 \mathrm{~mm}$ dan $40 \mathrm{~mm}$; dan pada posisi ROI center, arah jam 12, arah jam 3, arah jam 6 dan arah jam 9. Kriteria responden adalah radiografer yang menguasi pemeriksaan MRS dengan pengalaman melakukan pemeriksaan MRS selama lebih dari 5 tahun dan pernah mengikuti pelatihan MRI. Variabel kontrol pada penelitian ini adalah bottle phantom MRI $2000 \mathrm{ml}$, protokol MRS dengan sequence localizer center dan sequence single voxel spectroscopy (SVS) dan invalidate adjustment.

Analisis data dilakukan menggunakan analisis deskriptif untuk melihat profil FWHM dari pemilihan ROI yang berbeda pada MRS, kemudian dilakukan uji statistik dengan aplikasi SPPS 16 menggunakan uji Regresi Linier untuk mengetahui pengaruh pemilihan ukuran ROI terhadap nilai FWHM dengan nilai $\alpha=0,05(\mathrm{p}<0.05)$.

\section{HASIL}

Pada penelitian ini penulis melihat nilai FWHM dari pengaturan ukuran dan posisi ROI yang berbeda. Penulis menggunakan phantom MRI untuk mengontrol sample yang digunakan. Phantom diletakkan pada pertengahan meja pemeriksaan MRI, kemudian dilakukan scanning localizer center untuk memastikan objek berada di isocenter gantry MRI.
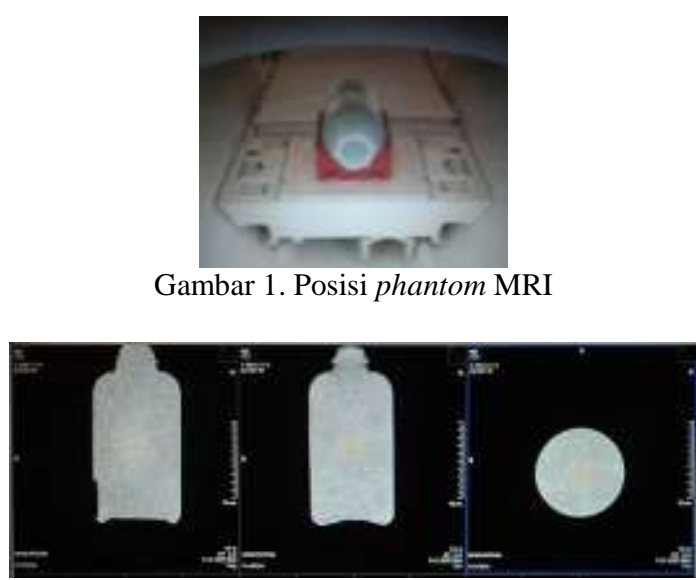

Gambar 2. Gambar localizer phantom sagital, coronal dan axial

Setelah didapatkan localizer sagital, coronal dan axial (Gambar 2), tambahkan sequence SVS 30, kemudian lakukan pengaturan ukuran ROI yang berbeda $(20 \mathrm{~mm}, 25 \mathrm{~mm}, 30 \mathrm{~mm}$, $35 \mathrm{~mm}$ dan $40 \mathrm{~mm}$ ) dan pada posisi ROI yang berbeda yaitu pada posisi ROI berikut:

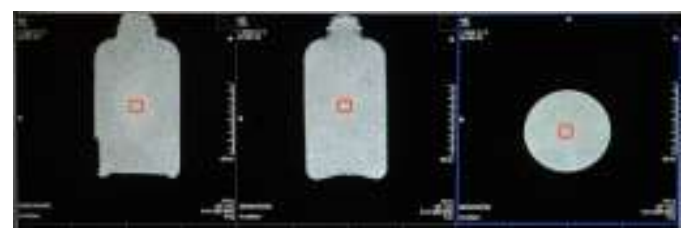

Gambar 3. Posisi ROI center

Gambar 3 menunjukkan posisi ROI center berada di pertengahan phantom. Setelah dilakukan pengaturan ROI pada posisi center, dilakukan pengaturan ukuran ROI yang berbeda ( $20 \mathrm{~mm}, 25 \mathrm{~mm}, 30 \mathrm{~mm}, 35 \mathrm{~mm}$ dan $40 \mathrm{~mm}$ ). ROI pada posisi center menghasilkan rata-rata nilai FWHM 15.75-22.16.

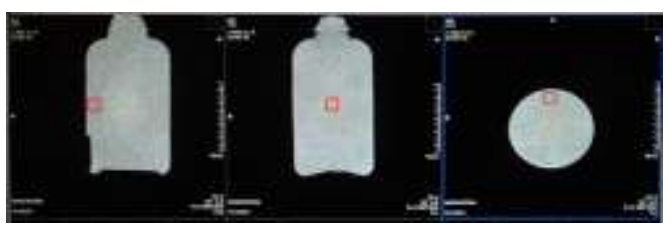

Gambar 4. Posisi ROI arah jam 12

Gambar 4 menunjukkan posisi ROI pada arah jam 12 pada potongan axial. ROI pada posisi arah jam 12 menghasilkan rata-rata nilai FWHM 27.375 - 37.02.

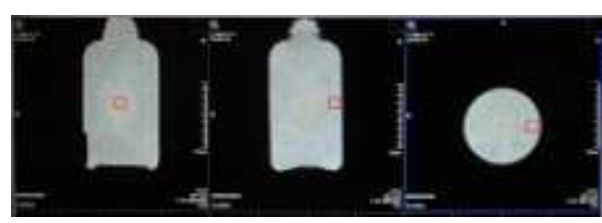

Gambar 5. Posisi ROI arah jam 3 
Gambar 5 menunjukkan posisi ROI pada arah jam 3 pada potongan axial. ROI pada posisi arah jam 3 menghasilkan rata-rata nilai FWHM 21.175 - 30.46.

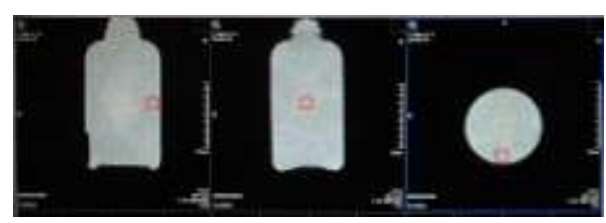

Gambar 6. Posisi ROI arah jam 6

Gambar 6 menunjukkan posisi ROI pada arah jam 6 pada potongan axial. ROI pada posisi arah jam 6 menghasilkan rata-rata nilai FWHM 9.15 - 10.28.

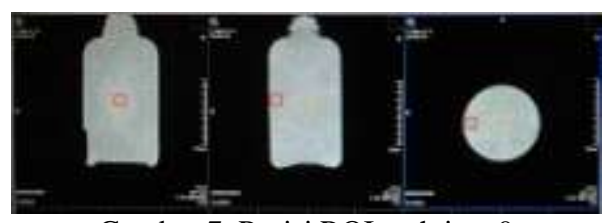

Gambar 7. Posisi ROI arah jam 9

Gambar 7 menunjukkan posisi ROI pada arah jam 9 pada potongan axial ROI pada posisi arah jam 9 menghasilkan ratarata nilai FWHM 22.05 - 29.56.

Untuk mempermudah dalam menganalisis nilai FWHM yang dihasilkan, nilai FWHM ditampilkan dalam bentuk tabel sebagai berikut:

Tabel 1. Nilai FWHM pada posisi dan ukuran ROI yang berbeda

\begin{tabular}{|c|c|c|c|c|c|c|}
\hline \multirow{2}{*}{ ROI } & \multicolumn{2}{|c|}{$20 \mathrm{~mm}$} & \multicolumn{2}{|c|}{$25 \mathrm{~mm}$} & \multicolumn{2}{|c|}{$30 \mathrm{~mm}$} \\
\hline & Mean & SD & Mean & SD & Mean & SD \\
\hline 0 & 15.75 & 0.0548 & 18.04 & 0.0548 & 19.44 & 0.0548 \\
\hline 12 & 27.375 & 0.0447 & 29.88 & 0.0447 & 32.88 & 0.0447 \\
\hline 3 & 21.175 & 0.0447 & 23.66 & 0.0548 & 25.9 & 0 \\
\hline 6 & 9.15 & 0.0548 & 9.2 & 0 & 9.4 & 0 \\
\hline 9 & 22.05 & 0.0548 & 24.32 & 0.0447 & 26.78 & 0.0447 \\
\hline \multirow{2}{*}{ ROI } & \multicolumn{3}{|c|}{$35 \mathrm{~mm}$} & \multicolumn{3}{|c|}{$40 \mathrm{~mm}$} \\
\hline & \multicolumn{2}{|c|}{ Mean } & SD & Mean & \multicolumn{2}{|c|}{ SD } \\
\hline 0 & \multicolumn{2}{|c|}{20.9} & 0 & 22.16 & \multicolumn{2}{|c|}{0.05477} \\
\hline 12 & \multicolumn{2}{|c|}{35.04} & 0.0548 & 37.02 & \multicolumn{2}{|c|}{0.04472} \\
\hline 3 & \multicolumn{2}{|c|}{28.6} & 0 & 30.46 & \multicolumn{2}{|c|}{0.05477} \\
\hline 6 & \multicolumn{2}{|c|}{9.7} & 0 & 10.28 & \multicolumn{2}{|c|}{0.04472} \\
\hline 9 & \multicolumn{2}{|c|}{28.62} & 0.0447 & 29.56 & \multicolumn{2}{|c|}{0.05477} \\
\hline
\end{tabular}

Nilai mean didapat dari rata-rata nilai FWHM setiap posisi dan ukuran ROI yang diambil sebanyak 5 kali. Nilai SD (Standar Deviasi) didapat dari perhitungan standar deviasi dari 5 kali pengambilan nilai FWHM pada masing-masing posisi dan ukuran ROI.Nilai SD dicari untuk melihat besar perbedaan nilai sampel terhadap rata-rata atau keragaman sampel.

Berdasarkan tabel 1 mengenai nilai FWHM pada ukuran dan posisi ROI yang berbeda, dapat diketahui dari nilai standar deviasi bahwa data yang homogen dihasilkan dari posisi ROI pada arah jam 6 dan data yang paling tidak homogen dihasilkan dari posisi ROI pada arah jam 9. Namun bila dilihat secara keseluruhan standar deviasi dari data nilai FWHM pada ukuran dan posisi ROI yang berbeda masih pada nilai standar deviasi yang rendah, yang berarti data nilai FWHM pada berbagai ukuran dan posisi ROI memiliki tingkat keragaman yang tidak terlalu tinggi.

Nilai FWHM optimum yaitu pada nilai 12-20 dihasilkan dari ukuran ROI 20-30 mm pada posisi ROI center. Ukuran ROI $20 \mathrm{~mm}$ pada posisi yang berbeda menghasilkan nilai FWHM terendah dibandingkan dengan ukuran ROI $25 \mathrm{~mm}$, $30 \mathrm{~mm}, 35 \mathrm{~mm}$ dan $40 \mathrm{~mm}$. Demikian juga dengan ukuran ROI $40 \mathrm{~mm}$ pada posisi yang berbeda menghasilkan nilai FWHM tertinggi dibandingkan dengan ukuran ROI 25 mm, 30 $\mathrm{mm}, 35 \mathrm{~mm}$ dan $40 \mathrm{~mm}$. Nilai minimum FWHM dihasilkan dari ukuran ROI $20 \mathrm{~mm}$ pada posisi arah jam 6, sedangkan nilai maksimum FWHM dihasilkan dari ukuran ROI $40 \mathrm{~mm}$ pada posisi center.

Nilai FWHM terendah dihasilkan dari pengaturan ukuran ROI $20 \mathrm{~mm}$. Semakin besar ukuran ROI, nilai FWHM yang dihasilkan semakin tinggi. Nilai FWHM tertinggi dihasilkan dari ROI pada posisi arah jam 12. ROI pada posisi arah jam 6 menghasilkan nilai FWHM yang hampir sama pada ukuran ROI yang berbeda. ROI pada posisi arah jam 3 dan arah jam 9 memiliki nilai FWHM pada rentang yang hampir sama.

Untuk mengetahui pengaruh ukuran ROI terhadap nilai FWHM yang dihasilkan, dilakukan analisis data menggunakan program SPSS dengan uji Regresi Linier.Sebelum dilakukan uji regresi linier dilakukan uji normalitas data dengan menggunakan uji Shapiro Wilk untuk mengetahui apakah data berdistribusi normal atau tidak normal. Berdasarkan hasil uji normalitas data didapatkan hasil nilai signifikasi pvalue $>0.05$. Hasil uji regresi linier pada nilai FWHM terhadap pengaturan ukuran ROI ditampilkan pada tabel berikut:

Tabel 2. Hasil uji regresi nilai FWHM terhadap ukuran ROI

\begin{tabular}{cccc}
\hline Posisi ROI & $\mathrm{R}$ & R Square & P value \\
\hline Center & 0.993 & 0.986 & \\
Arah jam 12 & 0.997 & 0.994 & \\
Arah jam 3 & 0.999 & 0.998 & $<0.05$ \\
Arah jam 6 & 0.941 & 0.885 & \\
Arah jam 9 & 0.853 & 0.727 & \\
\hline
\end{tabular}

Berdasarkan tabel 2 dapat dilihat bahwa nilai $R$ Square dari hasil uji regresi mendekati 1, sehingga dapat disimpulkan bahwa ada korelasi yang kuat antara pengaturan ukuran ROI terhadap nilai FWHM dengan koefisien korelasi sangat kuat. Sehingga dapat disimpulkan penggunaan ukuran ROI yang besar pada klinis, akan menghasilkan nilai FWHM yang tinggi bila dibandingkan dengan penggunaan ukuran ROI yang lebih kecil. Namun pengaturan ROI pada pemeriksaan MRS diatur berdasarkan ukuran dan jenis tumor maupun jaringan yang akan dilihat nilai metabolitnya.

\section{DISKUSI}

Dalam penelitian ini objek yang digunakan adalah phantom MRI untuk melihat profil nilai FWHM yang dihasilkan dari pengaturan ukuran ROI yang berbeda. Pada 
tabel 1.nilai FWHM pada ukuran ROI yang berbeda menunjukkan adanya peningkatan nilai FWHM terhadap perbesaran ukuran ROI. Hal ini berarti semakin besar ROI yang diatur, nilai FWHM semakin tinggi yang berarti homogenitas semakin menurun atau inhomogen. Pada nilai FWHM pada posisi ROI yang berbeda menunjukkan bahwa letak atau posisi ROI juga mempengaruhi nilai FWHM. Untuk melihat kenaikan nilai FWHM terhadap peningkatan ukuran ROI, dilakukan perhitungan presentase kenaikan nilai FWHM terhadap peningkatan ukuran ROI yang dihasilkan pada tabel 3.

Tabel 3. Presentase Kenaikan nilai FWHM terhadap Peningkatan Ukuran ROI

\begin{tabular}{ccccc}
\hline \multirow{2}{*}{$\begin{array}{c}\text { Posisi } \\
\text { ROI }\end{array}$} & $\begin{array}{c}\text { 20-25 } \\
\mathrm{mm}\end{array}$ & $\begin{array}{c}25-30 \\
\mathrm{~mm}\end{array}$ & $\begin{array}{c}30-35 \\
\mathrm{~mm}\end{array}$ & $\begin{array}{c}35-40 \\
\mathrm{~mm}\end{array}$ \\
\hline Center & $15 \%$ & $8 \%$ & $8 \%$ & $6 \%$ \\
12 & $9 \%$ & $10 \%$ & $7 \%$ & $6 \%$ \\
3 & $12 \%$ & $9 \%$ & $10 \%$ & $7 \%$ \\
6 & $1 \%$ & $2 \%$ & $3 \%$ & $6 \%$ \\
9 & $10 \%$ & $10 \%$ & $7 \%$ & $3 \%$ \\
\hline
\end{tabular}

Nilai presentase kenaikan nilai FWHM terhadap peningkatan ukuran ROI didapat dari nilai FWHM yang dihasilkan dari ukuran ROI $25 \mathrm{~mm}$ dikurangi nilai FWHM yang dihasilkan dari ukuran ROI $20 \mathrm{~mm}$, kemudian dibagi dengan nilai FWHM yang dihasilkan dari ukuran ROI $20 \mathrm{~mm}$. Perhitungan tersebut dilakukan juga pada nilai FWHM yang dihasilkan dari ukuran ROI yang lain, sehingga didapatkan nilai presentase kenaikan nilai FWHM terhadap peningkatan ukuran ROI. Berdasarkan tabel 3 presentase kenaikan nilai FWHM terhadap peningkatan ukuran ROI, dapat dilihat bahwa kenaikan nilai FWHM terhadap peningkatan ukuran ROI tidak konstan dan tidak selalu sama.

Presentase kenaikan nilai FWHM terhadap peningkatan ukuran ROI dengan presentase peningkatan paling rendah dihasilkan dari nilai FWHM pada posisi ROI arah jam 6. Nilai FWHM pada posisi ini mengalami peningkatan terhadap peningkatan ukuran ROI dengan presentase 1-6\%, sedangkan pada ROI pada posisi lain dihasilkan presentase peningkatan nilai FWHM sebesar 3-15\%. Menurut Bluml (2013), nilai FWHM hanya dapat diamati pada satu waktu atau real time. Hal ini karena nilai FWHM dihasilkan dari kandungan metabolit suatu benda maupun jaringan, dimana metabolit suatu atom akan selalu mengalami pergerakan pada istilah ini biasa disebut dengan chemical shift. Sehingga kenaikan nilai FWHM terhadap peningkatan ukuran ROI tidak konstan dan tidak selalu sama.

Menurut Hornak (2014), nilai FWHM yang optimum adalah pada nilai 12 - 20. Pada penelitian ini FWHM optimum dengan nilai 12 - 20 dihasilkan dari ukuran ROI 20 - $30 \mathrm{~mm}$ pada posisi center. Hal ini sesuai dengan teori susceptibilitas magnet dan $\mathrm{B}_{0}$ inhomogenity bahwa bagian isocenter akan lebih homogen. Hal ini disebabkan oleh $\mathrm{B}_{0}$ inhomenity dan susceptibility. $\mathrm{B}_{0}$ inhomeneity ini menyebabkan distorsi citra. Distrosi dalam hal spatial maupun intensitas. Distorsi intensitas menghasilkan $\mathrm{B}_{0}$ inhomeneity pada suatu area. Pada area ini memiliki FID yang berbeda sehingga sinyal yang dihasilkan pun berbeda. Ketika homogenitas rendah, FID akan menurun dan sinyal yang dihasilkan pun juga menurun. Sedangkan susceptibility adalah sifat kemagnetan yang dimiliki suatu material dalam menghasilkan medan magnet. Hal ini menyebabkan sifat magnetic di sekitar objek akan tertarik sehingga menghasilkan senyal yang berbeda pula. Susceptibility biasanya meningkat pada lokasi isocenter medan magnet, sehingga homogenitas meningkat, FID meningkat dan sinyal yang dihasilkanpun meningkat.

Dari hasil penelitian pada tabel 1 nilai FWHM pada ukuran ROI yang berbeda, nilai FWHM pada posisi arah jam 6 menghasilkan nilai FWHM yang rendah dengan nilai FWHM 9.15 - 10.28 dengan presentase peningkatan yang paling rendah pula yaitu $1-6 \%$ disbanding dengan presentasi kenaikan nilai FWHM pada posisi ROI yang lain. Hal ini dikarenakan posisi ROI arah jam 6 yang dekat dengan surface coil. Menurut Drost (2002), semakin rendah nilai FWHM, tingkat homogenitas semakin baik. Namun hal ini tidak diikuti dengan peningkatan SNR, dimana SNR sendiri merupakan salah satu factor yang mempengaruhi kualitas spektrum yang dihasilkan pada pemeriksaan MRS.

Dari hasil Regresi Linier pada Anova dihasilkan nilai signifikasi $p$ value $<0.05$ maka Ho ditolak dan Ha diterima, maka ada pengaruh secara signifikan dari ukuran ROI yang diatur terhadap nilai FWHM yang dihasilkan. Untuk melihat hubungan ukuran ROI yang diatur terhadap nilai FWHM pada posisi ROI yang berbeda secara keseluruhan, dapat dilihat nilai persamaan garis dengan kriteria regresi linier dengan fungsi linier yang ditampilkan pada grafik pengaruh ukuran ROI terhadap nilai FWHM pada posisi ROI center, arah jam 12, 3, 6 dan 9. Dari keseluruhan grafik dapat diketahui garis linier yang meningkat, sehingga dapat disimpulkan bahwa semakin besar ukuran ROI yang diatur nilai FWHM yang dihasilkan pun akan meningkat. Hal ini sesuai teori yang dikatakan Bulml (2013), semakin besar ROI yang diatur, metabolit yang terkandung di dalamnya juga semakin banyak, sehingga nilai FID menurun dimana nilai FID ini berbanding terbalik dengan nilai FWHM sehingga FWHM yang dihasilkan akan meningkat.

Hal ini berarti penggunaan ROI sekecil mungkin dapat menghasilkan nilai FWHM serendah mungkin, sehingga homogenitasnya pun semakin baik. Namun pada praktik klinis tidak dapat diterapkan demikian. Averaging juga diperlukan untuk memperoleh sampel dari metabolit suatu jaringan yang akan dilihat.

Keterbatasan dari penelitian ini adalah objek penelitian yang digunakan yaitu berupa phantom. Digunakan phantom sebagai objek penelitian untuk mengontrol sampel. MRS merupakan pemeriksaan klinis pada kasus tumor dimana sering kali dijumpai ukuran, lokasi, bentuk dan jenis tumor yang bervariasi dengan kandungan metabolit yang berbeda pula yang menghasilkan nilai FWHM yang berbeda pula, sehingga sampel tidak terkontrol. Disamping itu akan membutuhkan waktu untuk mengumpulkan sampel penelitian 
dengan kriteria tertentu untuk mengontrol sampel. Disamping itu penggunaan objek phantom ini dapat digunakan sebagai objek penelitian karena pada penelitian ini hanya melakukan survey pemilihan ROI terhadap nilai FWHM yang dihasilkan, tidak sampai pada menghasilkan spektrum MRS. Dengan penggunaan phantom ini peneliti juga lebih mudah mengontrol sampel yaitu pada posisi phantom di dalam gantry, posisi ROI pada phantom dan adjustment.

\section{SIMPULAN}

Semakin kecil ukuran ROI, nilai FWHM yang dihasilkan semakin rendah dan tingkat homogenitas semakin tinggi. Sebaliknya, semakin besar ukuran ROI, nilai FWHM yang dihasilkan semakin tinggi dan tingkat homogenitas rendah (inhomogen). Nilai FWHM optimum dihasilkan pada ukuran ROI 20 - $30 \mathrm{~mm}$ pada posisi center.

Dari hasil uji regresi linier dihasilkan nilai sig $<0.05$ sehingga dapat ditarik kesimpulan bahwa terdapat pengaruh dari pengaturan ukuran ROI terhadap nilai FWHM yang dihasilkan.

\section{DAFTAR PUSTAKA}

Bluml, Stefan. 2013. MR Spectroscopy of Pediatric Brain Disorders. Springer : USA.

Dick, J. Drost, William R. Riddle. 2002. Proton magnetic resonance spectroscopy in the brain. Report of AAPM MR Task Group \#9 : USA.

Horská, Alena, Ph.D. and Peter B. Barker, D. Phil. 2011. Imaging of Brain Tumors: MRS and Metabolic Imaging. Neuroimaging Clin N Am. http://www.ncbi.nlm.nih.gov/pmc/articles /PMC2927327/

John, Hesselink R., MD, FACR. 2007. Fundamentals of MRS. http://spinwarp.ucsd.edu/neuroweb/Text/mrs-TXT.htm.

Knoll, Glenn F. 2000. Radiation Detection and Measurement, 3rd edition. Hamilton : New York.

Miller, Janet Cochrane, D,Phil.; Uppot, Raul N, M.D. 2012. "Magnetic Resonance Spectroscopy in the Brain", Massachusetts General Hospital Department of Radiology, Volume 10, Issue 7. http://www.massgeneral.org/imaging/news/radrounds/july_2012/.

Sachin, Gujar K MD; dkk. 2005. "Magnetic Resonance Spectroscopy", Journal of Neuro-Ophthalmology, Volume 25, Issue 3 . http://journals.lww.com/jneuroophthalmology/Fulltext/2005 /09000/Magnetic_Resonance_Spectroscopy_.15.aspx.

Siemens. 2005. MR Spectroscopy Quick Guide. Germany.

Tsao, Connie M.D. 2008. Basic MRI Physics. Wikidoc Harvard Medical School : USA.

Upadhyay, MBBS, MRes and A D Waldman, PhD, FRCR. 2011. "Conventional MRI evaluation of gliomas", International Journal of Radiology, Radiation Onkologi and all related science, Volume 84, Issue 2. http://www.ncbi.nlm.nih.gov/pmc/articles/ PMC3473894/.

Westbrook, Catherine; Carolyn Kaut Roth and John Talbot. 2000. MRI in Practice, 4th edition. Blackwell Science : USA. 